\title{
The Long and Winding Road to Equality and Inclusion for Persons with Disabilities : The United Nations Convention on the Rights of Persons with Disabilities
}

Citation for published version (APA):

Broderick, A. (2015). The Long and Winding Road to Equality and Inclusion for Persons with Disabilities : The United Nations Convention on the Rights of Persons with Disabilities. [Doctoral Thesis, Maastricht University]. Intersentia. https://doi.org/10.26481/dis.20151120ab

Document status and date:

Published: 01/01/2015

DOI:

10.26481/dis.20151120ab

Document Version:

Publisher's PDF, also known as Version of record

Please check the document version of this publication:

- A submitted manuscript is the version of the article upon submission and before peer-review. There can be important differences between the submitted version and the official published version of record.

People interested in the research are advised to contact the author for the final version of the publication, or visit the DOI to the publisher's website.

- The final author version and the galley proof are versions of the publication after peer review.

- The final published version features the final layout of the paper including the volume, issue and page numbers.

Link to publication

\footnotetext{
General rights rights.

- You may freely distribute the URL identifying the publication in the public portal. please follow below link for the End User Agreement:

www.umlib.nl/taverne-license

Take down policy

If you believe that this document breaches copyright please contact us at:

repository@maastrichtuniversity.nl

providing details and we will investigate your claim.
}

Copyright and moral rights for the publications made accessible in the public portal are retained by the authors and/or other copyright owners and it is a condition of accessing publications that users recognise and abide by the legal requirements associated with these

- Users may download and print one copy of any publication from the public portal for the purpose of private study or research.

- You may not further distribute the material or use it for any profit-making activity or commercial gain

If the publication is distributed under the terms of Article $25 \mathrm{fa}$ of the Dutch Copyright Act, indicated by the "Taverne" license above, 


\section{Summary in English}

The research conducted for this book has been triggered by the establishment of the DREAM (Disability Rights Expanding Accessible Markets) network of research, which had as its primary objective to educate the next generation of disability entrepreneurs and to take the norms of the CRPD out of their theoretical box to promote substantive change for persons with disabilities in practice.

This book examines several aspects of the equality and non-discrimination norms in the CRPD. In the first instance, this book provides an interpretation and critical analysis of the legal meaning of the principles of equality and non-discrimination in the context of the CRPD. It analyses the extent to which the concepts of equality and non-discrimination contained in the Convention fit within the various theoretical models of disability and conceptions of equality that have been elaborated to date by scholars and compares the theoretical framework of equality in the CRPD to that contained in other international human rights treaties which preceded the Convention. The aim of that interpretation is both to tease out States' obligations under the Convention and to facilitate a demonstration of how the non-discrimination tool contained in the CRPD can potentially be leveraged to promote lasting reforms and true equality for people with disabilities. A particular focus throughout this book is on the manner in which the equality and non-discrimination norms in the CRPD can increase participation and inclusion in society of persons with disabilities. This book also examines in detail an integral component of the equality norm under the CRPD, namely the duty to reasonably accommodate persons with disabilities and, in particular, its outer limits. In that regard, the research conducted for this book analyses whether the balancing and sharing of burdens inherent in the accommodation duty (namely, the fact that the covered party is obliged to accommodate the needs of a disabled individual, unless that would amount to a disproportionate burden for the entity concerned) can teach us lessons about the overall balancing of burdens and interests implicit in many Convention rights subject to progressive realisation? Following on from that, this book devises a framework for review of measures taken by States in the overall context of the progressive realisation of disability rights, with a particular emphasis on how the CRPD's equality norm might strengthen the realisation of socio-economic rights for disabled people. That framework of review criteria is then applied to the right to education and the accessibility obligation incumbent on States under the CRPD. Finally, this book investigates how the equality and non-discrimination norms in the Convention have already influenced, and can potentially influence, the crucial shape of disability equality case law and policy. It identifies the challenges which lie ahead in the implementation of the Convention. In that connection, a case study is carried out on the Council of Europe mechanisms, in 
order to assess whether the CRPD is having an influence on disability law and policy at the regional level. This facilitates an analysis of whether the equality and nondiscrimination norms in the CRPD can be used to expand disability discrimination claims in the Council of Europe.

\section{InTERpretation OF THE Equality and Non-Discrimination Norms IN THE CRPD}

The non-discrimination norm in the CRPD can be described as embodying substantive and transformative models of equality. The substantive model of equality seeks to target covert forms of discrimination, as well as ensuring that differential characteristics are accommodated within the equality norm. In particular, the duty to accommodate under the Convention consolidates the substantive approach to equality, imposing an obligation on States to take positive measures to ensure that entities provide reasonable accommodations to disabled people, with a view to increasing equality of opportunities, as well as de facto equality. The accommodation duty brings a redistributive element into the non-discrimination norm under the CRPD. In addition, the legitimation of temporary and permanent positive action under the CPRD seeks to accelerate and achieve de facto equality for persons with disabilities. Positive action can be linked intrinsically to the substantive equality paradigm by virtue of the fact that it seeks to increase participation and inclusion in the mainstream by targeting historical and ongoing unequal power relations between persons with disabilities and their non-disabled counterparts. Overall, the CRPD underscores its vision of substantive equality with positive measures aimed at accelerating the concrete fulfilment of the principle of equality in the context of persons with disabilities.

The CRPD goes beyond a pure substantive equality model to endorse a transformative equality model. The Convention's overall mandate seeks to target deep-rooted structural inequalities, systemic prejudices and institutional biases. The provisions of the CRPD on the whole aim at ensuring a reallocation of resources in favour of persons with disabilities. They are designed to guarantee empowerment of disabled people and to foster their inherent abilities in order that persons with disabilities can participate and be included fully in mainstream society on an equal basis with others. The transformative model of equality can be seen quite clearly by means of the CRPD's accessibility obligations, its universal design provisions and its awarenessraising duties, as well as in the Convention's application of the equality norm (via the reasonable accommodation duty) to each of the substantive rights contained in the Convention, particularly socio-economic rights. The transformative model of equality in the CRPD is underpinned by its social-contextual understanding of disability and its human-rights based approach to disability. Those far-reaching models of disability aim at creating inclusive structures and ensuring that persons with disabilities are provided with the material support necessary to achieve equality in fact, thereby reaching their full potential and capabilities. The CRPD's endorsement of the social model of disability has resulted in the reconfiguration of 
the equality norm for persons with disabilities - it acknowledges that the full and effective participation and inclusion of people with disabilities can only be achieved through the realisation of a barrier-free society.

The understanding of the equality norm has evolved greatly in recent years, both at the level of international human rights law and in the disability context, from embodying a formal model of equality to endorsing a more substantive and even transformative conception of equality. Oddný Mjöll Arnardóttir highlights the fact that in the era of "universal sameness, '1 there was no accommodation for difference. The open-ended non-discrimination provisions and the universal equality norm applied to everyone in the same manner, regardless of difference. This is evidenced by such instruments as the ICCPR and the ICESCR. Over time, international human rights law began gradually to recognise differential characteristics in the quest for true equality. The next era that can be detected at the level of international human rights law has been termed the 'specific difference'2 equality era. The substantive difference model of equality which is characteristic of that era forms the basis of the non-discrimination provisions in both CERD and CEDAW. ${ }^{3}$ Those treaties view discrimination based on specific identity markers or biological and immutable characteristics as worthy of special attention, but only in certain circumstances. Both treaties incorporate the notion of indirect discrimination in their non-discrimination clauses and they also permit the taking of special measures or positive action, wherever necessary. However, the focus under the specific difference era remained with differential characteristics rather than with wider disadvantage in mainstream society. Before the CRPD, the emphasis was largely on differential characteristics as an exception to the rule of equal treatment. The CRPD can be deemed to represent the culmination of previous steps in the direction of substantive and transformative models of equality. Oddný Mjöll Arnardóttir characterises the era culminating with the adoption of the CRPD as embracing 'multidimensional disadvantage's equality. The substantive disadvantage model of equality underlying the CRPD displays a true understanding of structural inequalities. The substantive disadvantage model advocates legal tools such as indirect discrimination, positive action, reasonable accommodations and other positive measures as integral means by which to eradicate barriers which maintain or perpetuate disadvantage. The CRPD strengthens the nondiscrimination norm in many respects. The inclusion of the duty to accommodate within the non-discrimination provision guarantees an individualised application of the equality paradigm and has increased the potential for ensuring de facto equality. The CRPD recognises the fact that the universal equality norm must be tailored to the specific needs of disabled people. It breathes new life into the Convention's guarantees in accordance with the lived realities of disabled people. Furthermore, the CRPD adopts a contextual approach to equality - it seeks to target asymmetrical

\footnotetext{
1 O.M. Arnardóttir, 'A Future of Multidimensional Disadvantage Equality' in O.M. Arnardóttir and G. Quinn, The UN Convention on the Rights of Persons with Disabilities: European and Scandinavian Perspectives (Martinus Nijhoff, Leiden, 2009), at page 47.

Ibid, at page 49 .

Ibid.

Ibid.
} 
structures of disadvantage and oppression and shifts the target of non-discrimination laws to deeply unequal structures in society. Finally, the CRPD embraces a multidimensional or intersectional approach to non-discrimination, recognising the fact that discrimination arising from a number of grounds in combination produces a unique discriminatory experience for the individual concerned. In that regard, the CRPD goes further than the other core human rights treaties, which do not mention multiple or intersectional discrimination explicitly within their text.

In addition, the CRPD goes beyond any of the other core human rights treaties in seeking to ensure a transformative approach to equality. CEDAW requires States to take all appropriate measures to eliminate prejudices, customary and other practices, which are based on the idea of the inferiority or the superiority of either of the sexes or on stereotyped roles for men and women. The CRPD requires States to target, in addition, all socially constructed barriers which hinder de facto equality and full and effective participation and inclusion in society for disabled people. It is clear that this will require the adoption of a wide variety of positive measures in all spheres of society and a significant reallocation of resources to ensure equality of opportunity and equality in fact. On the basis of the foregoing, there is no doubt that the CRPD holds enormous promise for the future application of the equality and non-discrimination norms in relation to the rights of persons with disabilities. Among other things, it is hoped that the interaction of the equality norm and socio-economic rights in the Convention may provide the key to unlocking the structural inequalities faced by disabled people, in order to bring them fully into the mainstream. Notwithstanding this, the realisation of de facto equality for persons with disabilities will be a significant challenge for many States, not only on account of obvious resource and institutional constraints, but also because the Convention requires widespread attitudinal change regarding the inherent capabilities of persons with disabilities and the potential contribution which they can make in mainstream society.

\section{The Outer Limits of the Duty to Accommodate}

This book also examines the outer limits of the duty to accommodate persons with disabilities. Three principal lessons can be drawn from an examination of the outer limits of the duty to accommodate. The first of these is that any requested accommodation must be necessary and appropriate in the circumstances of a particular, individualised case. Translating the concept of necessity to the context of progressive realisation, this implies that States will be required to take all essential measures towards ensuring that persons with disabilities can begin to enjoy CRPD rights and towards ensuring the full realisation over time of Convention rights. The criterion of appropriateness translates to the requirement that measures adopted by States must be effective in allowing the disabled person in question to participate in the required activity and in contributing towards realisation of the substantive rights and obligations contained in the CRPD. Linked to the notion of effectiveness of measures is the concept of human dignity and the equality norm. 
The duty to accommodate is based on the core values of human dignity and respect for difference. These values, taken together with a consideration of the object and purpose of the duty to accommodate (the promotion of equality and the elimination of discrimination), will be essential to any determination of whether measures taken by private entities or States are effective. The third lesson drawn from the outer limits of the duty to accommodate rests on an underlying proportionality test. That test endeavours to balance the rights of, and burdens and benefits to, all persons affected by the proposed accommodation. Burdens or costs will not be merely financial in nature but will also extend to a consideration of the level of difficulty for a particular entity in terms, for instance, of the manner in which the accommodation affects the entity's business. It was also argued that third-party benefits should be considered in the provision of accommodations under the CRPD. In deciding whether a measure constitutes a disproportionate burden for an entity, regard should be had to the manner in which a requested accommodation has knock-on effects, not only for the entity concerned, but also for other individuals, such as individuals with comparative disabilities or potentially even consumers of an entity. All of these elements of the duty to accommodate have the potential to map over to the context of progressive realisation. In a similar vein to the accommodation duty, the realisation of the Convention's substantive rights and obligations is characterised by an implicit balancing of burdens and interests between the duty-bearer and the rights-holder. In order to ensure an appropriate balancing of needs and interests between States (and entities), on the one hand, and disabled individuals, on the other hand, it is necessary to place a normative framework around the progressive realisation of CRPD rights, both in terms of resource allocation and programme and policy design. This book went on to propose such a framework, based on 'reasonableness review' criteria, incorporating the outer limits of the duty to accommodate and drawing on frameworks of reasonableness review under South African constitutional jurisprudence and the OP-ICESCR.

\section{A Proposed Framework for the Progressive Realisation OF CRPD RightS}

In a similar vein to some of the outer limits of the duty to accommodate (which apply to entities), the outer limits of the progressive realisation norm will be adjudicated on by the CRPD Committee in accordance with the resources available to States, as well as priorities set by national authorities, among other considerations. In that regard, the Committee will be tasked with assessing State action or inaction based not only on the needs of persons with disabilities, but also in light of resource and institutional or capacity constraints in a given State. The Committee must acknowledge the fact that the needs and interests of others, including other marginalised groups in society, will be a relevant consideration for national authorities when they allocate resources. It was argued in this book that the measures adopted by States within available resources should be adjudged according to their reasonableness. Accordingly, several frameworks of reasonableness review at the national and international levels were explored - specifically, the criteria adopted under South African Constitutional 
jurisprudence and the emerging notion of reasonableness review envisaged under the OP-ICESCR. The research conducted for this book sought to explore the criteria inherent in already existing frameworks of reasonableness review to tailor them to the specific context of the CRPD in order to advance its equality paradigm. It was demonstrated that the types of criteria inherent in already existing frameworks of reasonableness review would fit well in the assessment of measures taken by States to fulfil their obligations under the CRPD. By virtue of the fact that the socio-economic provisions in the CRPD are linked intrinsically to the equality norm via the duty to accommodate, the outer limits of the duty to accommodate were also drawn on in order to inject an additional equality dimension into the review of CRPD rights realisation. In sum, the outcomes for this portion of the research project were as follows:

In realising disability rights progressively, national authorities are required to take necessary measures to give effect, at the very least, to the minimum core of the right(s) in question in order to ensure that the basic needs and capabilities of persons with disabilities are catered for. States are also required to take essential measures to ensure that the totality of CRPD rights will be realised in the fullness of time. In line with the criterion of effectiveness, any steps taken by governments to realise progressively CRPD rights must produce tangible outcomes, which are compatible with the requirements of the Convention. States must also ensure that the least restrictive measures are put in place to facilitate the realisation of socio-economic rights. In deciding whether measures taken by States are in compliance with the Convention, the CRPD Committee must balance cost-related factors against many other considerations. States will make policy choices regarding priority-setting in their own national contexts. This raises very difficult issues, to which there is no definitive solution. Nonetheless, the types of policy choices made by States must be justified and thereafter judged according to their reasonableness. In spite of the resource and institutional constraints weighing on national authorities, there is a duty incumbent on those authorities to utilise whatever resources and capacity they have in a manner which accords a sufficient degree of priority to the values underlying the Convention as a whole. The Committee's review framework must be grounded in the normative content of the right(s) at issue (including the minimum core), together with an analysis of the broader object and purpose of the Convention. Minimum thresholds for assessment of socio-economic rights are important, but not sufficient on their own, to guarantee the full and effective realisation of the rights of disadvantaged groups, such as persons with disabilities. As such, equality should be a paramount consideration in any framework of reasonableness review, as the CRPD links States' obligations to eliminate disability discrimination with guarantees for the full realisation of socio-economic rights. Incorporating equality into a review framework under the CRPD would serve to ensure that States Parties to the Convention put forward heightened justifications for any alleged rights violations. This, in turn, would serve to highlight instances in which the denial of access to the socio-economic right in question results in the entrenchment of inequalities or marginalisation for persons with disabilities. An approach to socio-economic rights adjudication based on equality would bolster the human-rights based approach to 
disability, which underlies the Convention as a whole, and would seek to overturn the misguided stereotypes which exist regarding the capabilities of disabled persons.

Another related criterion that will be important in any assessment of socio-economic rights under the CRPD is the underlying core norm of the inherent dignity of persons with disabilities. While there are several criticisms of the use of human dignity as a normative guide to human rights implementation, the research in this book provided counter-arguments to that. Moreover, it argued that there are two strands to the concept of human dignity which have particular relevance to the CRPD. The first of these requires that consideration be given to the urgency of needs of different groups. States must respond accordingly to ensure that those urgent needs are catered for. The second strand of human dignity in international human rights law involves an alignment with the equality norm and requires consideration of the equal worth of all human beings. It involves treatment as an equal. In the context of the CRPD, dignity considerations must be examined relative to both strands of human dignity. In the first instance, the needs of disabled persons who are in most dire circumstances must be catered for. Once this basic level of provision has been satisfied, dignity should feature thereafter as an equality concern, whereby the full realisation of socio-economic rights under the CRPD takes account of the equal worth of persons with disabilities and their entitlement to enjoy rights on an equal basis with others. Of course, national authorities will not have limitless resources to spend on disability rights and therefore the Committee will be required to balance the right to equality (including dignity considerations) against an assessment of costs in order to determine if particular measures constitute a disproportionate burden on States.

In the overall assessment of what constitutes a disproportionate burden on States, the CRPD Committee will have to ask whether national authorities have used all powers at their disposal to ensure resource prioritisation and resource optimisation, including through international assistance. In that connection, the Committee must ensure that States do not act in a discriminatory or arbitrary manner. States must ensure that any resources they have are used efficiently in order to implement fully (within available resources) disability rights, as well as the rights of all marginalised groups in society. In addition to the foregoing, the Committee should look to the impact of failure to take measures in implementing socio-economic rights for persons with disabilities. Thus, for instance, if a failure to take measures in one context leads to depriving persons with disabilities of what may be essential to enable them to enjoy other rights vested in them under the Convention, this may be a relevant factor in the CRPD Committee's assessment of State measures.

Participatory processes will also be essential to ensuring accountability in the implementation of Convention rights. In deciding on priorities for the realisation of socio-economic rights in the context of limited resources, input from disabled persons organisations and civil society groups will be vital to determining the greatest needs of citizens. It will also facilitate the effective implementation of rights, by identifying the measures that are most suited to the realisation of rights in various 
contexts. Another potentially relevant (albeit tangential) consideration is the issue of the benefits accruing to persons other than the disabled individual in question (such as persons with a comparative disability or even non-disabled persons).

Having considered the overall link between progressive realisation and equality, the research carried out for this book went on to examine two substantive rights and obligations subject to progressive realisation, namely the accessibility obligation and the right to education under the CRPD.

\section{The Interrelationship between the ACCessibility Obligation and THE EQUality NoRM}

The link between the CRPD's accessibility obligation contained in Article 9 and the equality and non-discrimination norms in the Convention is delineated in this book, including the overlaps and key differences between the two. The Convention's accessibility obligation breathes new life into the equality norm. The obligations imposed on States Parties to the CRPD under Article 9 aim to guarantee equal life opportunities for persons with disabilities in line with those enjoyed by their non-disabled peers. The effective implementation of the Convention's accessibility provisions is a precondition for full participation and inclusion in society. While accessibility standards and measures may facilitate access to human rights and, in some cases, may ensure de facto equality, this will not always be the case. In such circumstances, States must go further in their endeavours to ensure effective implementation of both Article 5 and Article 9 of the Convention in tandem, including monitoring implementation of measures such as reasonable accommodations and positive action.

The CRPD Committee will have the difficult task of adjudicating the efforts of States to ensure disability accessibility, while at the same time ensuring the realisation of other socio-economic rights and obligations in the CPRD. In light of the fact that Article 9 is a resource-intensive obligation, the Committee will have to consider the issue of what constitutes a disproportionate burden for a particular State. States will be required to justify their policy choices to the Committee, which will have to ask itself whether national authorities have taken measures that ensure the most cost-effective implementation of Article 9 by, for instance, considering accessibility issues at the beginning of the design of products, services and buildings. If States have not taken reasonable cost-effective measures (not imposing a disproportionate burden), this may lead to a finding by the Committee of a potential violation of Convention obligations. Of course, not all measures required to ensure disability accessibility will, by definition, be cost-effective (especially those taken to retrofit facilities or infrastructure). In that regard, the Committee should ask itself whether States have ensured an optimal use of (limited) resources targeted at realising disability accessibility and whether they have prioritised resources in that regard. If a given State has not done so, this may lead to a finding by the Committee that the State has not taken all reasonable measures to implement CRPD rights. A further 
relevant consideration is whether States have consulted closely with and involved persons with disabilities in all aspects of implementation of disability accessibility, as required under Article 4(3) of the Convention. This will allow a determination of whether States have adopted measures which are most effective and which are least restrictive of the rights of persons with disabilities. To that end, disabled persons and their representative organisations should be consulted closely in the development of products, services and facilities, as well as in the development, promulgation and monitoring of minimum standards for the accessibility of different facilities and services provided by public and private enterprises. In the overall assessment of whether measures impose a disproportionate burden on a State, the Committee may evaluate the extent to which particular accessibility measures would have benefits to a wider cohort of individuals, beyond disabled persons, and thereby the extent to which such measures contribute to the Convention's universal design provisions. The issue of third-party benefits may be fraught with difficulties and any assessment in that regard would have to be considered cautiously by the Committee.

One of the primary factors that should feature in the CRPD Committee's assessments is that of equality. As always, equality arguments must be balanced against the notion of disproportionate burden. In that vein, one must acknowledge the impact of limited resources and respect the sovereignty of a State to make appropriate choices in its national context. Notwithstanding this, the Convention clearly mandates accessibility of the environment, structures, and so forth, for disabled persons on an equal basis with others. Thus, the Committee will have to judge whether, in setting priorities, States have had regard to the extent to which measures adopted by them to ensure accessibility will actually contribute to achieving the overall goals of equalising opportunities and outcomes for persons with disabilities. A fundamental premise of accessibility measures adopted by States is that persons with disabilities should be guaranteed equivalent or functionally equivalent access to non-disabled people. Closely related to equality issues is the fact that disabled people should not be required to use or access goods, services, infrastructure or other facilities in a manner which compromises their human dignity. States should therefore ensure consideration of dignity interests in all aspects of the implementation and monitoring of Article 9, including in the design of accessibility standards.

There is no doubt that the equality and non-discrimination norms in the CRPD are closely entwined with the accessibility obligation. By applying equality and dignity considerations as key criteria in the implementation of Article 9, this can serve to ensure that disabled people are treated as true equals in the enjoyment of socio-economic rights. States must therefore ensure effective implementation of both Article 5 and Article 9 of the Convention in tandem. Guarantees of equality and non-discrimination should be interpreted by national judicial authorities in a manner which facilitates and promotes the Convention's accessibility requirements. Accessibility and equality measures should be coherent and coordinated with a view to ensuring that the overall objective of the CRPD - namely the achievement of de facto equality for persons with disabilities - is realised in the most efficient and effective manner possible. 


\section{The Right to Education for Persons with Disabilities}

This book also elaborates on the meaning of equality in the context of the right to education and teases out the potential value which the equality and non-discrimination norms in the CRPD can add to the right to education for persons with disabilities. In addition, this book applies the various criteria that may be employed by the CRPD Committee in assessing compliance with Article 24.

The costs of providing inclusive education will be an obvious factor to be taken into account by the CRPD Committee in its assessment of State action or inaction. In that regard, it is noteworthy that inclusive education is often mistakenly viewed as being prohibitively costly. However, research has demonstrated the fact that many positive educational measures are not very expensive. Inclusive educational settings are generally less expensive than segregated systems, when appropriately implemented. Nonetheless, resource implications will be a concern for many States in implementing Article 24 of the CRPD, particularly developing States, and the transformation of special educational systems to fully inclusive systems may incur significant outlays in terms of resources (both human and financial), at least in the transitional phase. On the other hand, the CRPD Committee must bear in mind the fact that the cost benefits of inclusive education are assured in the long term and that the implementation of inclusive education can assist in the realisation of the right to education for non-disabled children also. In that vein, the CRPD Committee will be required to assess whether States are ensuring an efficient and effective use of existing resources (including resources which are being poured into special educational systems), as existing resources can potentially be harnessed to assist the mainstream provision of education. It will be particularly important to ensure rights-based and performance-based budgeting in order to identify the areas where existing resources can be more efficiently targeted to implement the right to inclusive education, among other rights, for persons with disabilities.

As with all other rights contained in the Convention, the non-discrimination and equality provisions are of paramount importance in implementing Article 24 of the CRPD. In many cases, access to mainstream education is being hindered for a large proportion of disabled individuals who are being placed in segregated educational settings. Ensuring access to inclusive education and equal educational opportunities for disabled people will require the removal of barriers to participation and inclusion. This will involve fundamental changes in physical structures and facilities, educational curricula and in the processes of learning to accommodate different learning styles and means of communication. Overall, it must be emphasised that Article 24 reflects the human rights-based approach to educational provision. Article 24 of the CRPD mandates truly inclusive and accessible educational structures. In tandem with equality considerations, dignity considerations for persons with disabilities will be paramount to the CRPD Committee's assessment of the measures taken by States to ensure implementation of Article 24 of the CRPD. One of the main challenges which lies ahead for States in the implementation of the right to inclusive education is the elimination of discrimination and stigmatisation of the capabilities of persons with 
disabilities in terms of learning outcomes and so forth. Under the CRPD, States must undertake awareness-raising campaigns and persons with disabilities must be given the material support to ensure that their inherent potential is allowed to develop in education, as in all other areas.

According to Article 24, any support provided within mainstream education must facilitate the effective education of disabled persons. States should conduct research into the effectiveness of current inclusive education policies. The CRPD Committee will have to keep a close watch on the collection of data and the establishment of national educational benchmarks and indicators, which will allow States Parties to the CRPD to monitor the effectiveness of measures taken in the realisation of the right to education for persons with disabilities. In order to ensure enjoyment of the right to education for persons with disabilities on a truly equal basis as others, their input, through participatory processes, is vital as this is the key to unlocking structural inequalities which have hindered the right to education for disabled people for far too long now.

On the basis of all of the above, it is abundantly clear that the Convention's equality and non-discrimination norms have huge potential to impact on the implementation of socio-economic rights for persons with disabilities. However, this potential must be realised properly through the application of defined and equitable criteria to the rights and obligations contained in the Convention.

\section{The Influence of the CRPD on Council of Europe Disability Law AND Policy}

The final part of the research for this book entails a case study on the Council of Europe. The first part of that case study relates to the influence to date, and the potential influence, of the CRPD on the disability equality case law of the European Court of Human Rights (ECtHR). In the second part of the case study, the provisions of the Revised European Social Charter (revised Charter) are considered, as well as the views of the European Committee of Social Rights (ECSR) and the general disability policy of the Council of Europe. The aim of that second part of the case study is to explore the influence which the CRPD is having on those Council of Europe legal and policy mechanisms.

The CRPD is exerting some degree of influence on the relevant organs in the Council of Europe. However, the extent of its impact varies quite considerably between the various legal and policy mechanisms in the Council. The CRPD is certainly guiding the general direction of disability policy through the recommendations and issue papers of the Committee of Ministers. Those non-binding instruments are drawing quite heavily on relevant elements from the substantive provisions of the CRPD as an interpretative guide for Member States in their implementation of disability rights. Many of the instruments adopt the fundamental values and principles underlying the Convention, particularly in relation to equality/non-discrimination and 
inclusion in society for persons with disabilities. Many of the documents also draw specific guidance from the concrete provisions of the Convention in formulating recommendations and suggestions to be employed by Member States in their implementation of disability rights.

In terms of tangible effects of the CRPD on the case law of the ECtHR, the Court has cited the Convention on numerous occasions in the context of relevant international law since the coming into force of the CRPD. However, the Court is not always consistent in referring to the Convention and the reasons for its failure to refer to the CRPD are not always clear from one case to another. One can only surmise that the Court is not quite sure of the relevance of CRPD provisions to ECHR rights. Notwithstanding the Court's inconsistent approach, the CRPD appears to be having some positive influence on judgments of the ECtHR with regard to disability discrimination and also on the standard of scrutiny adopted by the Court. The Court has included some form of implicit duty to accommodate within Article 14 and has begun to incorporate a social-contextual or social model reasoning in certain selected judgments. It has also referred to the CRPD as an example of a European and worldwide consensus on the need to protect people with disabilities from discriminatory treatment. In addition, the ECtHR has demonstrated an increased awareness of the impact of historical discrimination on persons with disabilities and links this to the applicable margin of appreciation of States. On the other hand, the Court has not yet recognised an explicit right to be accommodated under Article 14 as an essential means of ensuring disability equality in the enjoyment of ECHR rights. It is envisaged that the social-contextual approach which the Court is beginning to adopt, together with the evolutive interpretative approach that it professes to employ, will play a greater role in the future. In light of the fact that the majority of Member States of the Council of Europe are also party to the CRPD and will, thus, be incorporating reasonable accommodation duties into their national legislative frameworks (where they have not already done so), this might encourage the Court to recognise the substantive disadvantage experienced by persons with disabilities in society and to incorporate this into its analysis of ECHR rights.

Not many disability-related collective complaints have been taken before the ECSR since the coming into force of the CRPD. Therefore, it is difficult to measure the Convention's impact or potential impact in that regard. To date, the ECSR is referring to the CRPD in the context of relevant international law but the Convention has not actually had a concrete influence on the Committee's reasoning. Nonetheless, the provisions of the revised Charter overlap, to a large degree, with many substantive rights contained in the CRPD, including the right to education and the right to independent living. The education line of case law appears to provide most scope for the interpretation of rights under the revised Charter in a manner which is compatible with the CRPD.

It is evident that there will be significant challenges ahead in translating the progressive approach to equality contained in the CRPD into legislation and policy at the European level and, specifically, in the Council of Europe. In particular, the 
process of change will be a slow and arduous one at the level of the judicial system, especially in the ECtHR. There will also be many barriers ahead for persons with disabilities in their efforts to turn the aspirations of the Convention into individually justiciable rights. In spite of the challenges inherent in the process of change, the CRPD still holds great promise for the future application of the equality and nondiscrimination norms, provided of course that this potential is realised and utilised by policy-makers and the judiciary. 